\title{
STRATEGI PEMBELAJARAN EACH ONE TEACH ONE DAPAT MENINGKATKAN HASIL BELAJAR BAHASA INDONESIA SISWA KELAS IV SD NEGERI 1 KALIREJO SEMESTER GANJIL TAHUN PELAJARAN 2019/2020
}

\author{
Suharto 1 \\ ${ }^{1}$ SD Negeri 1 Kalirejo \\ Correspondence Email: suharto_1245@gmail.com
}

Received: Apr 23, $2020 \quad$ Revised: Apr 26, $2020 \quad$ Accepted: Apr 30, 2020

\begin{abstract}
ABSTRAK
Guru di SD Negeri 1 Kalirejo sudah cukup kreatif dalam melakukan pembelajaran namun, hal ini masih belum cukup untuk meningkatkan kemampuan peserta didik dalam membaca teks dan menentukan pikiran utama yang bisa dibaca dengan tepat. Guru merasa kesulitan untuk mengatur suasana kelas yang tidak kondusif dikarenakan pembelajaran dirasa membosankan sehingga peserta didik tidak dapat berkonsentrasi dalam pembelajaran. Selain itu faktor penunjang. Faktor penunjang antara lain, kurangnya referensi buku mengenai membaca teks dan menentukan pikiran utama yang bisa dibaca dengan tepat. Dari hasil evaluasi Bahasa Indonesia Kelas IV, masih belum tuntas tentang materi membaca teks dan menentukan pikiran utama. Sehingga buku referensi atau referensi lainnya sangat diperlukan agar peserta didik tidak merasa kesulitan dalam pembelajaran membaca teks dan menentukan pikiran utama dengan strategi pembelajaran each one teach one dapat meningkatkan kemampuan membaca teks dan menentukan pikiran utama yang dibaca Kelas IV SD Negeri 1 Kalirejo tahun pelajaran 2019/2020.

Desain penelitian dalam penelitian ini adalah PTK dengan berkolaborasi dengan guru yang dilakukan 2 siklus. Dalam PTK ada 4 tahapan yaitu perencanaan, tindakan, observasi dan refleksi. Data primer dengan menggunakan tes ulangan dan observasi dengan di checklist, dan data sekunder dengan wawancara. Peneliti menggunakan keharusan nilai sasaran atau KKM (Kriteria Ketuntasan Minimal) menentukan kriteria sukses untuk menganalisis data. Berdasarkan rumusan masalah, hasil penelitian, dan pembahasan, simpulan dari penelitian tindakan kelas ini adalah sebagai berikut: adanya peningkatan kemampuan membaca teks dan menentukan pikiran utama dengan Strategi pembelajaran each one teach one Kelas IV SD Negeri 1 Kalirejo Tahun Pelajaran $2019 / 2020$.
\end{abstract}

Kata Kunci : Strategi pembelajaran each one teach one, hasil belajar

\section{PENDAHULUAN}

Berdasarkan hasil prasiklus yang sudah dilakukan, diketahui bahwa nilai ratarata keterampilan membaca teks dan menentukan pikiran utama rendah masih dibawah KKM yaitu $85 \%$. Berdasarkan hasil tersebut dapat dsimpulkan bahwa membaca teks dan menentukan pikiran utama pada kelas IV masih rendah dan perlu adanya perbaikan 
untuk meningkatkan membaca teks dan menentukan pikiran utama. Dari beberapa penyebab tidak maksimalnya kemampuan membaca teks dan menentukan pikiran utama peserta didik, peran guru sangat penting. Model dan media haruslah yang menarik minat peserta didik agar tetap fokus dan berkonsentrasi dalam pembelajaran, sehingga hasil yang diinginkan akan maksimal. Berkaitan dengan hal tersebut, Membaca teks dan menentukan pikiran utama yang dibaca menggunakan strategi pembelajaran each one teach one bahwa Paul Ginnis (2008:154) mengatakan pada strategi ini, menuntut semua siswa aktif dalam belajar.

Agar dapat menjelaskan sesuatu, siswa harus memahaminya. Jika siswa memahami sesuatu, siswa mengingatnya. Juga, beliau mengatakan bahwa penelitian mengungkapkan bahwa siswa belajar dengan lebih efisien dari rekannya daripada dari guru. Berdasarkan penjelasan tersebut, dapat dipahami bahwa Strategi pembelajaran each one teach one merupakan suatu alternatif untuk meningkatkan hasil belajar siswa yang selama ini cenderung rendah. Karena strategi pembelajaran each one teach one dapat membantu siswa saling bekerja sama dengan orang lain, membantu siswa mengelola informasi dengan baik, dan meningkatkan hasil belajar siswa.

Strategi pembelajaran each one teach one digunakan untuk menunjukkan serangkaian kegiatan guru yang terarah yang menyebabkan hasil belajar siswa meningkat.

Faktor peserta didik adalah minat yang kurang dari diri peserta didik itu sendiri untuk berlatih Membaca teks dan menentukan pikiran utama yang dibaca. Peserta didik kesulitan untuk menuangkan gagasannya ke dalam sebuah tulisan. Selain itu, cara penyampaian hasil kerja peserta didik dalam bentuk lisan masih terpaku pada teks sehingga terlihat seperti membaca teks. Minat peserta didik juga karena tidak adanya media yang menarik sehingga peserta didik merasa bosan dalam mengikuti pembelajaran di kelas. Hal tersebut juga terjadi karena faktor kedua yaitu guru.

Guru di SD Negeri 1 Kalirejo sudah cukup kreatif dalam melakukan pembelajaran namun, hal ini masih belum cukup untuk meningkatkan kemampuan peserta didik dalam Membaca teks dan menentukan pikiran utama yang dibaca. Guru merasa kesulitan untuk mengatur suasana kelas yang tidak kondusif dikarenakan pembelajaran dirasa membosankan sehingga peserta didik tidak dapat berkonsentrasi dalam pembelajaran. Selain itu faktor ketiga adalah penunjang. Faktor penunjang antara lain, kurangnya referensi buku mengenai membaca teks dan menentukan pikiran utama. Di dalam buku teks bahasa Indonesia kelas IV, masih kurang materi tentang membaca 
teks dan menentukan pikiran utama. Sehingga buku atau referensi lainnya sangat diperlukan agar peserta didik tidak merasa kesulitan dalam pembelajaran Membaca teks dan menentukan pikiran utama yang dibaca.

\section{METODE PENELITIAN}

\section{Desain Penelitian}

Penelitian tindakan kelas adalah penelitian tindakan (action research) yang dilaksanakan oleh guru di dalam kelas. Kemmis dan Mc. Taggart (dalam Ekawarna, 2011:5) menjelaskan langkah penelitian tindakan kelas ada empat, yaitu perencanaan, tindakan, observasi, dan refleksi. Kedua ahli ini menyatukan tindakan dan observasi sebagai satu kesatuan. Hasil observasi kemudian dijadikan dasar sebagai langkah berikutnya, yaitu refleksi. Penelitian ini menggunakan desain PTK dengan dua siklus yaitu proses tindakan pada siklus I dan siklus II. Siklus I bertujuan untuk mengetahui keterampilan Membaca teks dan menentukan pikiran utama yang dibaca peserta didik dan siklus II bertujuan untuk mengetahui peningkatan keterampilan Membaca teks dan menentukan pikiran utama yang dibaca setelah dilakukan perbaikan dalam kegiatan belajar mengajar yang didasarkan pada refleksi siklus I. Tiap siklus terdiri atas empat tahap, yaitu perencanaan, tindakan, pengamatan, dan refleksi. Berikut adalah desain proses penelitian menurut Kemmis dan Mc. Taggart (dalam Ekawana, 2011:16) yang akan dilakukan peneliti.

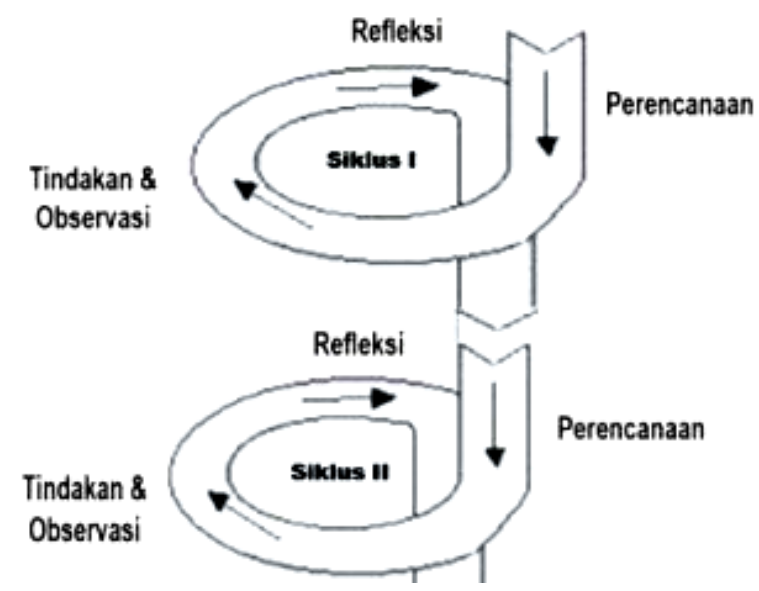

Gambar 3.1 Desain Penelitian Tindakan Kelas

\section{Prosedur Penelitian Tiap Siklus}

Proses tindakan pada siklus I meliputi perencanaan, tindakan, observasi, dan refleksi. Pembahasan hal tersebut sebagai berikut ini. 


\section{Perencanaan}

Pada tahap ini, peneliti melakukan perencanaan untuk menentukan langkahlangkah pembelajaran dan memperbaiki pembelajaran Membaca teks dan menentukan pikiran utama yang dibaca. Pada tahap perencanaan penelitian hal-hal yang dilakukan meliputi

(1) berkoordinasi dengan guru kelas mengenai rencana penelitian,

(2) menyusun rencana pembelajaran pelaksanaan pembelajaran (RPP),

(3) menyiapakan materi yang akan diajarkan,

(4) mempersiapkan instrumen penelitian berupa lembar observasi, rubrik penilaian dan pedoman wawancara,

(5) mempersiapkan alat untuk dokumentasi.

\section{Tindakan Tiap Siklus}

Pada tahap ini peneliti melakukan tindakan sesuai dengan rencana pembelajaran. Pada kegiatan pembelajaran akan dilaksanakan dengan tiga tahap yaitu,

a. Kegiatan pendahuluan

1) Guru memberikan apersepsi kepada siswa sesuai dengan materi yang akan dibahas. Guru menciptakan suasana kelas yang religius dengan menunjuk salah satu peserta didik untuk memimpin berdoa. Selanjutnya guru memeriksa kehadiran peserta didik, kebersihan dan kerapian kelas. Kegiatan ini merupakan wujud dari kepedulian lingkungan dan rasa bertanggung jawab peserta didik.

2) Guru mengondisikan peserta didik agar siap mengikuti pembelajaran. Selanjutnya guru menyampaikan pembelajaran yang akan dilaksanakan

b. Kegiatan Inti

3) Selembar kertas yang berisi sejumlah pernyataan tentang fakta atau statistik tertentu dibagikan kepada setiap siswa, sepantasnya setiap siswa menerima pernyataan atau fakta yang berbeda.

4) Para siswa secara mandiri membaca pernyataan tertulis itu untuk paham dan yakin tentang apa maknanya.

5) Para siswa bergerak berkeliling (dapat searah jarum jam atau terserah guru) dan saling berbagi tentang pernyataan itu dengan siswa yang lain. Mereka diperbolehkan menjelaskan pengetahuannya tentang pernyataan itu dengan siswa lain sebanyak mungkin. 
6) Para siswa didorong untuk mempertajam penjelasannya dengan memberikan contoh-contoh yang relevan, atau dengan mengaitkan pernyataan tersebut dengan pernyataan siswa yang lain.

7) Setelah beberapa saat sesuai waktu yang ditentukan untuk mengkomunikasikan pernyataan/fakta tersebut, para siswa dapat bekerja dalam kelompok kecil-kecil untuk menggolongkan informasi yang mereka terima selama proses pembelajaran.

8) Pada akhir pembelajaran, wakil para siswa dapat menjelaskan mengapa mereka membuat klasifikasi seperti itu.

9) Temuan utama dapat dituliskan di papan tulis atau kertas plano di depan kelas.

c. Kegiatan penutup

10) guru memberikan refleksi dengan menegaskan kembali tentang materi pembelajaran yang baru saja diajarkan.

\section{Observasi}

Observasi, yaitu kegiatan mengamati perilaku peserta didik selama proses kegiatan pembelajaran berlangsung. Observasi dilakukan pada saat pembelajaran berlangsung, untuk mengetahui bagaimana reaksi peserta didik ketika mengikuti pembelajaran Membaca teks dan menentukan pikiran utama yang dibaca menggunakan strategi pembelajaran each one teach one dengan tema Membaca teks dan menentukan pikiran utama yang dibaca.

\section{Refleksi}

Tahap terakhir pada siklus I adalah refleksi. Peneliti menganalisis hasil data tes dan nontes. Peneliti mengkaji data hasil observasi proses pembelajaran, jurnal guru, hasil wawancara dan dokumentasi foto. Hal tersebut dilakukan untuk mengetahui keefektifan, tanggapan, dan saran dari peserta didik terhadap pembelajaran siklus I. Peneliti mengkaji hasil observasi sikap spiritual dan sikap sosial peserta didik untuk mengetahui bagaimana perubahan sikap peserta didik selama pembelajaran siklus I. Setelah mengkaji data nontes, kemudian peneliti mengoreksi dan mengkaji hasil tes Membaca teks dan menentukan pikiran utama yang dibaca secara tertulis yang dilakukan peserta didik pada siklus I. Setelah dilakukannya peniaian pada nontes dan tes, selanjutnya adalah menganalisis kekurangan-kekurangan selama pembelajaran siklus I. Kekurangankekurangan tersebut terkait proses, model, dan media pembelajaran pada siklus I. Kekurangan-kekurangan tersebut seanjutnya akan diperbaiki pada pembelajaran siklus II. 


\section{HASIL PENELITIAN DAN PEMBAHASAN}

Berdasarkan rencana yang telah disusun bersama antara peneliti dan guru, maka pelaksanaan pertemuan pertama Pembelajaran berlangsung selama $2 \times 35$ menit, pelaksanaan pertemuan pertama ini sudah mulai menggunakan Strategi pembelajaran Each One Teach One pada Membaca teks dan menentukan pikiran utama yang dibaca.

Adapun langkah-langkah yang diambil oleh guru dengan dibantu oleh peneliti dalam menerapkan pembelajaran Strategi pembelajaran Each One Teach One pada setiap pertemuan adalah sebagai berikut:

1) Kegiatan pendahuluan (5')

Guru memberikan apersepsi kepada siswa sesuai dengan materi yang akan dibahas (ingin tahu)

2) Kegiatan Inti (65')

a) Guru menjelaskan tujuan pembelajaran (ingin tahu)

b) Selembar kertas yang berisi sejumlah pernyataan tentang fakta atau statistik tertentu dibagikan kepada setiap siswa, sepantasnya setiap siswa menerima pernyataan atau fakta yang berbeda. (ingin tahu)

c) Para siswa secara mandiri membaca pernyataan tertulis itu untuk paham dan yakin tentang apa maknanya. (ingin tahu)

d) Para siswa bergerak berkeliling (dapat searah jarum jam atau terserah guru) dan saling berbagi tentang pernyataan itu dengan siswa yang lain. Mereka diperbolehkan menjelaskan pengetahuannya tentang pernyataan itu dengan siswa lain sebanyak mungkin. (tanggung jawab)

e) Para siswa didorong untuk mempertajam penjelasannya dengan memberikan contoh-contoh yang relevan.(mandiri)

f) Setelah beberapa saat sesuai waktu yang ditentukan untuk mengkomunikasikan pernyataan/fakta tersebut, para siswa dapat bekerja dalam kelompok kecil-kecil untuk menggolongkan informasi yang mereka terima selama proses pembelajaran. (bekerja sama)

g) Pada akhir pembelajaran, wakil para siswa dapat menjelaskan mengapa mereka membuat klasifikasi seperti itu. (tanggung jawab)

h) Temuan utama dapat dituliskan di papan tulis atau kertas plano di depan kelas. (tanggung jawab)

3) Kegiatan penutup (10’) 
i) Guru memberikan tugas pelajaran rumah, pemberian tugas dimaksudkan untuk menyeimbangkan pengetahuan (mandiri).

Pelaksanaan pertemuan pertama siswa yang ditunjuk menjadi tutor. Siswa masih merasa agak kaku dengan lingkungan kelompok yang kurang kondusif. Namun pada kesempatan siswa untuk berfikir kreatif pada saat mengerjakan soal-soal. Siswa saling menukar jawaban untuk dikoreksi dengan bimbingan guru, hal ini dilakukan untuk meningkatkan interaksi sosial.

Peneliti juga mengadakan kolaborasi dengan guru bidang studi Bahasa Indonesia kelas IV dalam proses belajar mengajar. Penelitian berlangsung di kelas IV dengan cara guru membentuk kelompok kecil. Pada saat dibentuk kelompok siswa masih ramai bahkan guru pada saat mengajar pun masih kurang menguasai kelas disebabkan oleh siswa masih masa transisi dari model pembelajaran yang guru terapkan sehingga siswa pada saat guru mengadakan permainan dengan meminta siswa mencocokkan soal dengan jawabannya masih kaku. Namun perlu diadakan siklus II dikarenakan hasil belajar siswa kurang mencapai KKM yaitu 85\% hal ini disebabkan oleh siswa kurang mampu untuk mengerjakan soal dengan benar.

Peningkatan yang pesat pada prosentase hasil observasi tingkah laku siswa dalam keterlibatan siswa dalam belajar mengajar, antara lain meliputi siswa tidak takut atau berani dalam mengemukakan pendapat dalam belajar kelompok pada analisis observasi I di siklus I. sedangkan hasil belajar pada siklus 1 rata-rata nilai ulangan siswa kelas IV yaitu 71,88. Ketuntasan secara klasikal mencapai $68,75 \%$ atau 11 siswa yang tuntas dan siswa yang belum tuntas 5 siswa atau $31,25 \%$.

Berdasarkan hasil tes pada siklus I terdapat 5 siswa yang tidak tuntas belajar atau sebesar $31,25 \%$ yang memperoleh nilai $<70$. Hal ini menunjukkan bahwa penerapan Strategi pembelajaran Each One Teach One belum mencapai tujuan hasil belajar yang diharapkan, yaitu ketuntasan klasikal > 85\%. Ketercapaian secara klasikal di bawah ketentuan yang berlaku, yaitu $68,75 \%$. Hal tersebut bisa disebabkan kesalahan yang dilakukan siswa dan memang ada 2 siswa yang tidak masuk sekolah serta perlu perbaikan dalam tindakan (guru dan peneliti). Sedangkan pada siklus II hasil belajar siswa yang memperoleh nilai > 70 dan sebanyak 14 siswa atau sebesar 87,50\% yang memperoleh nilai > 85\%. Sebagian besar siswa telah memahami yang berhubungan dengan pemahaman konsep pada materi Membaca teks dan menentukan pikiran utama yang dibaca dengan baik, yang ditunjukkan dengan penurunan ketidaktuntasan siswa 
secara perseorangan dan peningkatan hasil belajar secara klasikal lebih dari $24 \%$ yaitu mencapai $87,50 \%$.

Berdasarkan penjelasan hasil belajar siswa, semakin membuktikan bahwa penerapan pengajaran Strategi pembelajaran Each One Teach One dapat meningkatkan hasil belajar siswa. Secara keseluruhan ketuntasan hasil belajar yang dicapai setelah tindakan mengalami peningkatan dari pada sebelum dilakukan tindakan yaitu $68,75 \%$ pada siklus I, dan $87,50 \%$ pada siklus II.

Berdasarkan penjelasan tersebut secara umum dapat dijelaskan bahwa penerapan Strategi pembelajaran Each One Teach One dapat meningkatkan hasil belajar dan dapat pula meningkatkan tingkah laku siswa yang positif dalam belajar. penerapan Strategi pembelajaran Each One Teach One ini membutuhkan kemampuan guru untuk bisa mengelola kelas dengan baik. Perlu kesiapan dan kematangan strategi yang diterapkan harus tepat sasaran. Penyelenggaraan pembelajaran harus sesuai dengan skenario pembelajaran yang telah dirancang bersama dengan peneliti. penerapan Strategi pembelajaran Each One Teach One ini sudah menunjukkan pencapaian pendekatan proses belajar yang dapat mempertajam proses pemahaman dan daya membuat belajar sebagai suatu proses yang menyenangkan dan bermanfaat.

\section{Simpulan}

Berdasarkan rumusan masalah, hasil penelitian, dan pembahasan, simpulan dari penelitian tindakan kelas ini adalah sebagai berikut: adanya peningkatan kemampuan Membaca teks dan menentukan pikiran utama melalui Strategi pembelajaran each one teach one kelas IV SD Negeri 1 Kalirejo Tahun Pelajaran 2019/2020, secara keseluruhan ketuntasan hasil belajar yang dicapai setelah tindakan mengalami peningkatan dari pada sebelum dilakukan tindakan yaitu $68,75 \%$ pada siklus I, dan $87,50 \%$ pada siklus II. 


\section{DAFTAR PUSTAKA}

Anderson, M dan Anderson, K. 2003. Type Text in English I. Australia: Macmilan Education Australia RTY LTD.

Arikunto, Suharsimi. 2014. Penelitian Tindakan Kelas. Jakata: PT Bumi Aksara

Chaer, Abdul. 2007. Kajian Bahasa: Struktur Internal, Pemakaian dan Pembelajaran. Jakarta: Rineka Cipta.

Daryanto. 2013. Media Pembelajaran Peranannya Sangat Penting dalam Mencapai Tujuan Pembelajaran. Yogyakarta: Gavamedia.

Peraturan Menteri Pendidikan dan Kebudayaan Republik Indonesia Nomor 65 Tahun 2013 tentang Standar Proses Pendidikan Dasar dan Menengah. 2013. Jakarta: Menteri Pendidikan dan Kebudayaan Repbulik Indonesia.

Rahayu, Iin. 2012. Kata dan Pembentukan Kata dalam Baasa Indonesia. Iinfitria19.blogspot.com/2012/12/kata-dan-pembentukan-kata-dalambahasa.html Diunduh pada 2 Maret 2015 pukul 12.30

Sugihartono, Ranang Agung, Basendar \& Asmoro. 2010. Animasi Kartun dari Analog Sampai Digital. Jakarta: Indeks.

Sutirman. 2013. Media dan Model-Model Pembelajaran Inovatif. Yogyakarta: Graha Ilmu.

Suhandang, Kustadi. 2009. Retorika, Strategi, Teknik, dan Taktik Pidato. Bandung: Nuansa.

Taniredja, Tukiran dkk. 2010. Penelitian Tindakan Kelas untuk Pengembangan Profesi Guru Praktik, Praktis, dan Mudah. Bandung: Alfabeta. 203

Wiryasih. 2011. Menuju Masyarakat Informasi. Yogyakarta: UGM.

Yuniawan, Tommi. 2012. Terampil Retorika Berbicara. Semarang: UNNES PRESS.

Zaman, Saefu. 2011. Definisi dan Unsur-Unsur Kalimat. www.situsbahasa.info/2011/11/definisi-dan-unsur-unsur-kalimat.html Diunduh pada 2 Maret 2015 pukul 12.35 